Article

\title{
Undermining Demand Management with Supply Management: Moral Hazard in Israeli Water Policies
}

\author{
David Katz \\ Department of Geography and Environmental Studies, University of Haifa, Haifa 39105, Israel; \\ katzd@geo.haifa.ac.il; Tel.: +972-4-824-8106 \\ Academic Editors: Sharon B. Megdal, Susanna Eden and Eylon Shamir \\ Received: 21 February 2016; Accepted: 14 April 2016; Published: 20 April 2016
}

\begin{abstract}
Most water managers use a mixture of both supply-side and demand-side policies, seeking to capitalize on the relative advantages of each. However, supply augmentation undertaken to avoid overdrafts can reduce the effectiveness of demand management policies if the two strategies are not carefully integrated. Such a result can stem from a type of moral hazard phenomenon by which consumers, aware of the increases in potential supply, discount the importance of conservation. This is illustrated by the case of Israel. Initial national-scale water-supply projects were followed by over-extraction, which, in turn, compelled implementation of wide-spread demand management measures to reduce consumption. With the recent advent of large-scale desalination in Israel, public perception regarding the importance of conservation has diminished and consumption has increased-this, despite periodic drought conditions and critically low levels of water reserves.
\end{abstract}

Keywords: conservation; demand management; supply management; moral hazard; water policy

\section{Introduction}

Water management options have typically been categorized as either supply management or demand management. The former focuses on enlarging the amount of resources available, while the second focuses on reducing the amount of needed for consumptive purposes. Historically, civil and water engineers have focused on large-scale supply augmentation infrastructure projects, while economists and environmentalists have tended to advocate for efficiency improvements and conservation oriented policies typically associated with demand management (e.g., [1-4]). Each approach has its relative merits. Supply-side policies enlarge the pie, promoting possibilities for increased economic activity and avoiding the difficult social and political obstacles involved in such demand-side options as cutting water quotas or increasing prices. Demand management options are often cheaper, more economically efficient, and have less negative environmental impacts than supply augmentation [2-5].

Most countries (or municipalities or other water governing bodies) employ a mix of supply-side and demand-side management strategies. The relative emphasis placed on each shifts over time and according to circumstances. For instance, most developing countries tend to focus first on supply management, building water and sanitation infrastructure. Indeed, access to "improved" water supplies providing safe drinking water is one of the first priorities of many developing countries, even at low levels of economic development [6-8]. More advanced economies often shift their focus to demand management options, after basic infrastructure is in place and relatively low cost supply-side options have been exhausted. This is especially the case in countries or areas that have fully tapped readily available renewable resources. Demand management options are also more likely to be emphasized when dealing with immediate and/or short term issues such as drought adaptation, as supply-side options often necessitate longer planning horizons. 
Water scarcity already affects billions of people around the globe [9]. This situation is expected by many to worsen in the near future due to population growth, economic growth and climate change which is predicted to alter the quantity, timing, intensity, and duration of precipitation events, as well as increased evapotranspiration [10-12]. In order to address such challenges, many water managers and policymakers are actively pursuing both supply-side and demand-side management strategies concomitantly, hoping to capitalize on the relative advantages of each.

Simultaneous pursuit of both types of management strategies is often recommended within the extensive literature on Integrated Water Resource Management (IWRM) (e.g., [13-15]). There can be, however, tradeoffs between water management goals, whereby attempts to implement one type of policy, inadvertently reduces the effectiveness of the other. For instance, increases in technical efficiency can lead to "rebound effects", which can, at least partially, cause increases in consumption due to the reduced cost per unit of consumption or associated output $[16,17]$.

Another possible tradeoff, and the focus of this paper, is the risk that investing in significant expansion of supplies can inadvertently undermine various demand management policies, especially if the two strategies are not specifically developed in an integrated and mutually reinforcing manner. This can stem from a type of moral hazard phenomenon by which consumers, aware of the increases in potential supply, discount the importance of conservation. Such a result is likelier the more the government or water utilities emphasize the scale and/or merits of the supply augmentation projects. Thus, though water managers may be tempted to implement both types of policies under the assumption that they are complementary, they should be aware that in some cases they may work at cross-purposes, and thus, the effect of joint implementation may be less than the sum of the effects of each policy implemented in isolation.

To illustrate this potential conflict, this article demonstrates how Israel's large-scale adoption of seawater desalination has weakened public perception of water scarcity and therefore has undone much of the efforts invested over the past decades in public awareness regarding the importance of conservation. The public's perception of a reduction in water scarcity and, as a result, an attenuation in its conservation habits, come despite continued periodic droughts and critically low levels of water reserves. To support the article's argument, this case study presents both publically available data on water consumption as well as results of a randomized survey of the Israeli public's perceptions and knowledge regarding the water sector and the importance of water conservation.

The article proceeds as follows. The following section provides an overview of available renewable water resources in Israel and of indicators of national water scarcity. Section 3 provides a chronological review of shifts in Israeli water policy, from an emphasis on supply-side management strategies, such as large scale water pumping and conveyance projects, cloud-seeding, and large-scale wastewater reuse, to a heavier reliance on demand management policies such as reduction in water quotas, pricing mechanisms, and conservation campaigns. It then shows how the combination of increasing demand for water within Israel and by its neighbors, together with decreasing reliability of precipitation, led the government to pursue large-scale seawater desalination. Section 4 presents data on changes in water consumption over the period since the inauguration of desalination and results of a randomized survey of public perception of water scarcity and the importance of water conservation in order to show how conservation habits have changed since the advent of desalination. Section 5 presents a discussion of the case study results, and Section 6 presents concluding remarks.

\section{Overview of Available Water Resources in Israel}

Israel is a small (20,770 square kilometers, official pre-1967 boundaries), semi-arid country. Over $60 \%$ of its landmass is desert. It is densely populated (roughly 8.4 million inhabitants as of 2016 [18]), especially in the non-desert areas. Average annual renewable freshwater resources were long estimated at approximately 1600 million cubic meters ( $\mathrm{mcm}$ ) [19]; however, this estimate has been revised in recent years to roughly $1200 \mathrm{mcm}$ [20]. The non-desert portion of Israel is characterized by a Mediterranean climate, with the majority of the rainfall concentrated in the winter months, with 
long dry and hot summers, and high rates of evaporation. Because of geographical and topographic conditions - the non-desert area is long, narrow and hilly-much of the rainfall is lost to runoff to the Mediterranean Sea. Approximately 30\% of the natural water supply is from surface water (primarily the Sea of Galilee-the country's only lake), with almost all of the remainder coming from groundwater. Nearly all of the country's natural freshwater resources are transboundary in nature, being shared with the Palestinian Authority and Jordan, and to a lesser extent with Syria and Lebanon.

The Falkenmark index is a commonly referenced measure of national water scarcity. According to this index, countries with annual renewable water resources of less than 1000 cubic meters $\left(\mathrm{m}^{3}\right)$ per capita suffer from water scarcity and countries with less than $500 \mathrm{~m}^{3}$ per capita suffer from chronic or "absolute" water scarcity [21]. Using the upper-bound estimate of average annual renewable freshwater listed above $(1600 \mathrm{mcm})$, national per capita availability is at $190 \mathrm{~m}^{3}$, well below the threshold for chronic water scarcity. Using the revised estimate of water availability $(1200 \mathrm{mcm})$, the situation is even more dire, at less than $150 \mathrm{~m}^{3}$. As will be elaborated more fully in the following section, Israel has invested heavily in non-conventional water resource augmentation, such as cloud-seeding, treated brackish water, wastewater reuse, and, most recently, large-scale seawater desalination. Together, these non-conventional sources add roughly $1000 \mathrm{mcm}$ to the national annual water budget. Taking these water sources into consideration, using the two estimates above, annual per capita availability increases to approximately 260-310 $\mathrm{m}^{3}$; still well within the Falkenmark standard for chronic water scarcity.

Climate change models largely predict additional stress on the country's water supplies. Climate scientists have already identified trends of warming temperatures and decreasing precipitation over the last several decades. According to Alpert et al., "average temperature over the Mediterranean area has increased by $1.5-4{ }^{\circ} \mathrm{C}$ in the last 100 years" and "The precipitation above most of the Mediterranean shows a dominant negative trend in the last 50 years" ([22], p. 163). Other research has already identified increasing variability and uncertainty in temporal and spatial precipitation patterns in the region, and predicts a continuation of such trends [23].

Predictions regarding expected rainfall in the region differ by model. The combined results from nine climate models, using the A2 scenario of the International Panel on Climate Change (IPCC), for instance, predict a reduction of 2.5\%-9.5\% for the period 2045-2065 relative to the period 1961-1990 [24]. Results from the B2 scenario, however, are unclear [19]. Temperature is expected to increase (by 1.9-2.7 ${ }^{\circ} \mathrm{C}$ in the A2 scenario for the period 2045-2065 [20]). The region is also expected to have more frequent and longer duration heatwaves [25]. This may lead to an associated increase in evaporation, though recent research from the region shows that the relationship between temperature and surface-water evaporation is not linear, and that temperature increases may be offset by changes in wind patterns [26]. Another likely impact is salinization of the coastal aquifer due to sea-level rise $[27,28]$. One estimate predicts that each $50 \mathrm{~cm}$ rise in sea level would reduce the storage capacity of the coastal aquifer by $16.3 \mathrm{mcm}$ per kilometer of coast [29]. In summary, climate change is already evident and is expected to further reduce naturally available water resources.

\section{A Brief Review of Historical Supply and Demand Management in Israel}

Feitelson [30] divides Israeli water management into four distinct periods. The first, from the founding of the state in 1948 until 1964, he termed the "Hydraulic Mission Period". This was characterized by several large-scale water supply projects. It was during this period that the nation developed the Yarkon-Negev water project to bring water from the coastal plain to the Negev desert in the south. This was the largest water conveyance project of its kind in the world at the time [31]. The capstone of the period was the building of the National Water Carrier (NWC), completed in 1964, which brought water from the Sea of Galilee to the coastal plain, where the majority of the population lived. The NWC essentially connected almost the entire country into one centralized water delivery system. During this period the country also began heavy pumping of groundwater, which was eventually also incorporated into the NWC delivery system. 
During the second period, which lasted until roughly 1990, policy was also largely focused on supply augmentation, but this time by means of non-conventional sources. By the mid-1960s, shortly following the inauguration of the NWC, Israel had essentially utilized $100 \%$ of available renewable fresh-water supplies. The environmental toll of such intensive development of water supplies was tremendous. The flow of the Jordan River was reduced to less than $10 \%$ of its natural flow. The level of the Dead Sea, a terminal lake at the end of the Jordan River, began declining by over a meter per year. Many of the coastal streams were desiccated and their springs dried up completely [32]. In addition, saltwater intrusion began along the coastal aquifer.

The capture of the West Bank, Gaza, and the Golan Heights in 1967 did not result in substantial increases in water consumption [33]. Most of the relevant water resources were transboundary in nature and Israel had already been utilizing them prior to the war. By controlling this territory, however, Israel was able to regulate withdrawals from these areas in order to ensure that the water it was already using continued to be available.

Given the limited available resources, in order to address growing water demand due to a growing population and an increasing standard of living, Israel began to develop non-conventional water sources. A plan to develop large-scale seawater desalination did not come to fruition during this period due to high costs. Other technologies did take off, however, and substantially contributed to the countries available water supplies. The first was a cloud-seeding program, primarily in the north of the country. It is claimed that this program has added approximately $13 \%$ to annual rainfall [34,35], though these figures have been questioned by some [36].

Another major contributor to increased water supplies that occurred during this second period of water development was reuse of treated wastewater for irrigation purposes. Israel has become a world leader in wastewater reuse. As of the time of the writing of this article, over $80 \%$ of municipal sewage is treated and reused-by far, the highest rate in the world [37]. This adds over $400 \mathrm{mcm}$ to the national water budget, roughly a third of natural renewable supplies.

Some initial advancement was made on demand management during this period as well. Drip irrigation was developed, which had the effect of substantially reducing the water needs per unit of crop. Despite widespread adoption of this potential demand management technology, however, it did not reduce agricultural water consumption. Rather, with water for the agricultural sector still priced at below its market value (shadow price), it remained a quantity-rationed good. Thus, rather than leading to a decline in consumption with stable yields, the increase in efficiency produced significant gains in yields with the existing agricultural water allocations [38] — that is, it resulted in "more crop per drop" but not in less drops dedicated to crops.

The third period in Israel's water history, beginning in the 1990s and lasting until the advent of wide-scale desalination beginning in 2005, saw a shift from the supply-side dominated policies of the first two periods, to a greater emphasis on demand management. Facing recurring droughts, depleted aquifers and levels of the Sea of Galilee at record lows, often below the "red line" set by authorities as the minimum level necessary to avoid permanent ecological damage (see Figure 1), Israeli policy changed its focus to reducing consumption. The first and most significant area of reduced consumption was allocations of freshwater to the agricultural sector, which the government cut by nearly half during this period (Figure 2a). Some of this was compensated for by increased allocations of treated wastewater (Figure $2 \mathrm{~b}$ ), but, overall, freshwater consumption declined by roughly $25 \%$ to approximately the revised annual renewable rates of $1200 \mathrm{mcm}$.

With the decline in agricultural consumption, municipal consumption overtook agricultural consumption as the primary consuming sector of freshwater in the country (see Figure 2) and thus became a more prominent focus of demand management policies. Periodic restrictions on municipal use were put in place, such as on lawn watering, especially during drought periods. Low-flow toilets were mandated for new construction. However, unlike the agricultural and industrial sectors in Israel, water supplies to the municipal sector are not allocated by administrative quotas, and thus, not as amenable to command and control type regulation. The authorities, therefore, made use of other 
demand management tools. (For a review of Israeli demand management policies, see [39].) Prices on municipal water were gradually raised and several high-profile awareness raising campaigns were advanced by the water authority. Campaigns emphasized that "every drop counts", and newspapers and other popular media outlets began publishing the levels of the Sea of Galilee as a means of highlighting the water crisis.

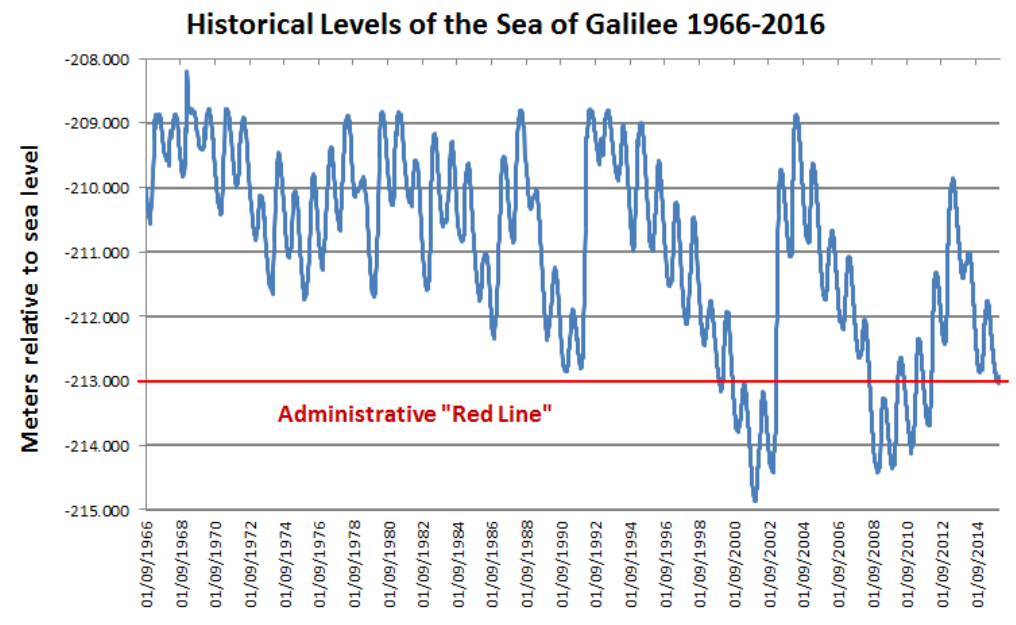

Figure 1. Historical levels of the Sea of Galilee (09/1966-01/2016). Based on Data from [40].

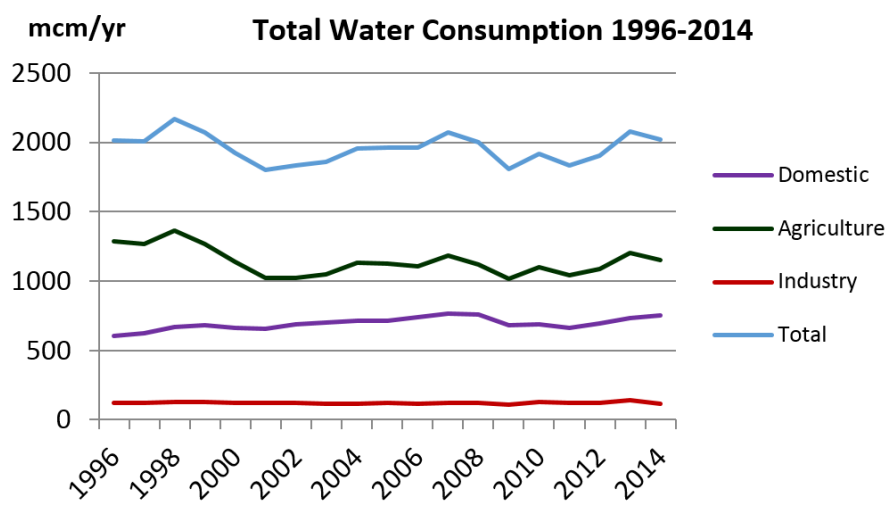

(a)

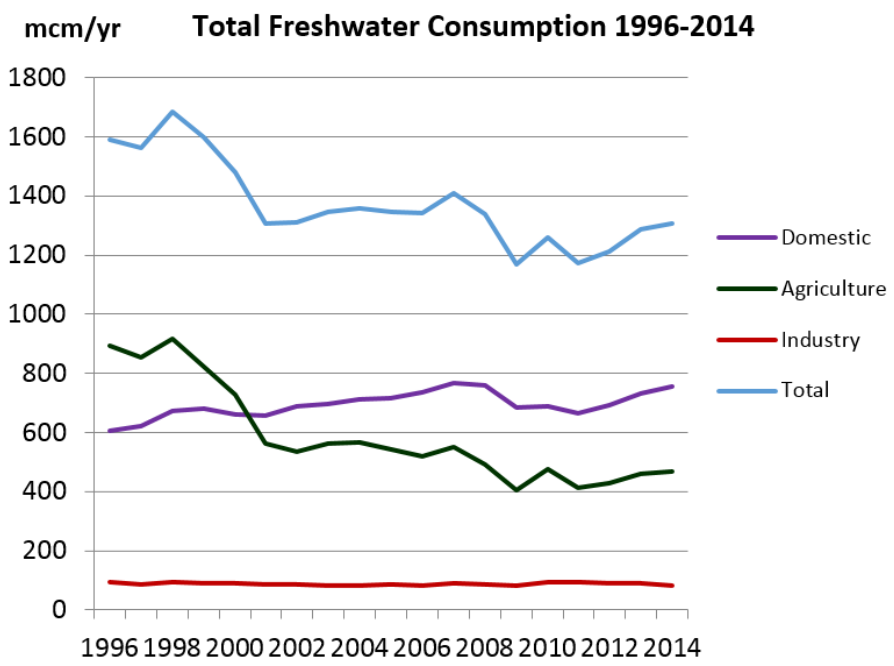

(b)

Figure 2. Cont. 
Domestic Per Capita Consumption 1996-2014

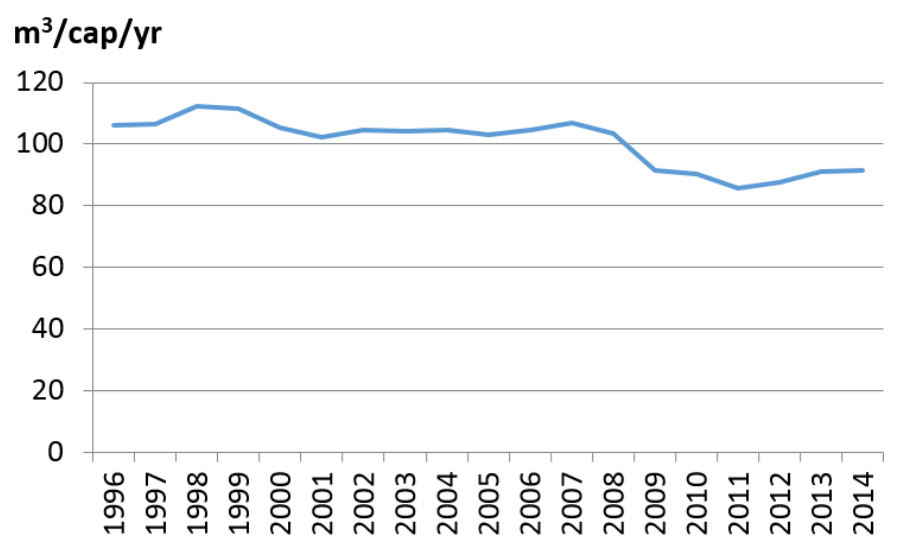

(c)

Figure 2. (a) total water consumption 1996-2014; (b) freshwater consumption 1996-2014; (c) domestic per capita water consumption 1996-2014. Based on data from [41].

During this period, however, new demands on freshwater were being made. The country was absorbing over a million new immigrants, primarily those coming from the former Soviet Union. Peace agreements with the Palestinians and Jordanians both contained clauses committing Israel to transfer more water to its neighbors. In addition, growing environmental awareness resulted in new demands for in-stream water allocations for ecological rehabilitation purposes [32]. During this period, Israel also experienced serious droughts. In order to accommodate the increased demands on scarce water supplies, concomitantly with the implementation of demand management, the government committed to long-term supply augmentation via seawater desalination.

The year 2005 marked the beginning of the fourth period in Israel's water management according to Feitelson, with the inauguration of the country's first large-scale desalination unit, adding $120 \mathrm{mcm}$ per year of freshwater. By 2013, the country had four large desalination plants operating, producing nearly $500 \mathrm{mcm}$, annually, and had commissioned yet another plant, due to come on line in 2016 and provide an additional $100 \mathrm{mcm}$ per year. Within less than a decade, collectively, desalination plants had become the country's single largest source of freshwater, providing more than the Sea of Galilee or any of the country's aquifers.

During the first few years of this period, when desalination was just coming online, water reserves were at historical lows and the country was experiencing a severe drought. Therefore, the authorities continued implementing demand management policies. Subsidies for water were reduced or eliminated across sectors. The average price of both agricultural and municipal water more than doubled between 2000 and 2010 [42,43], with most of the price increase coming in the post-desalination years (see Figure 3) (note: much of the spike in 2010 was a result of consolidation of water supply and sewage treatment into one payment, rather than pure price increases).

The cost of desalination was important (though not the sole) factor leading to price increases. According to the Israeli Water Authority, as of early 2016 desalination costs represented $16 \%$ of the cost of municipal water supply and treatment [43]. Other factors contributing to price increases included a removal of subsidies as part of a move towards full-cost pricing and a restructuring of municipal water supply from public to private water utilities. However, desalination was indirectly responsible for a greater share of the price increases than its mere share of the overall costs would indicate. This is because overall elimination of subsidies and promotion of full-cost recovery were among the measures put forth by the Ministry of Finance as conditions in order to gain its support for the costly desalination projects. 


\section{Average Water Tariff 1996-2016}

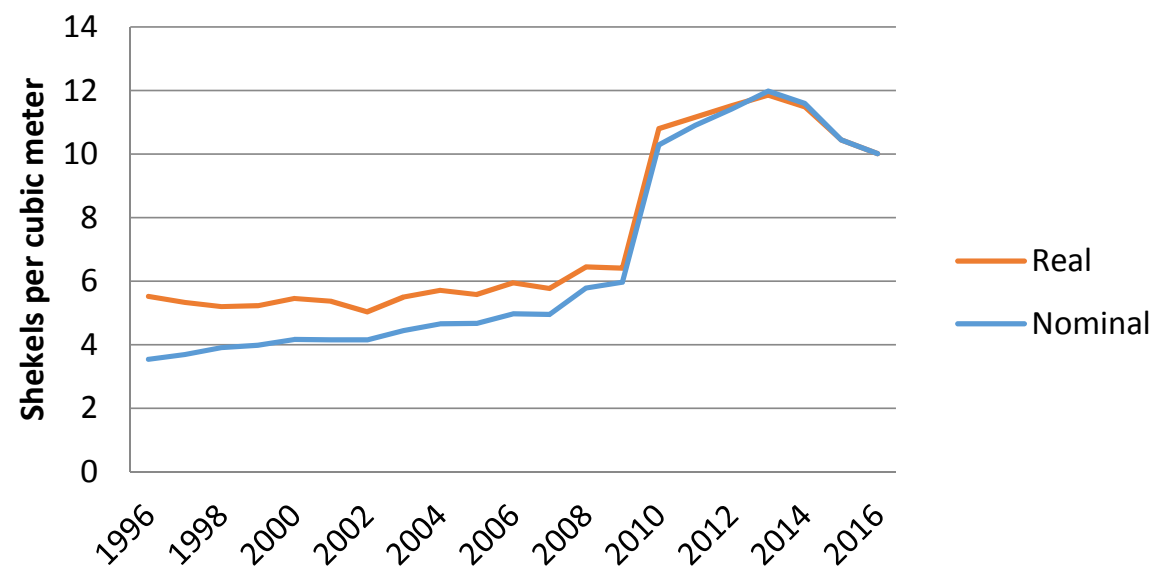

Figure 3. Average municipal water tariffs 1996-2016. Based on data from [43]. Real prices in 2016 shekels.

The Water Authority, the governmental body responsible for water management, also intensified its campaigns for conservation, enlisting several celebrities in its efforts. Assessments of the campaigns determined them to be effective [44], though, because they were implemented together with other demand management policies, and it is difficult to isolate the exact impact of the campaigns alone [45]. Other conservation measures were also implemented, for instance, distribution of low-flow faucet filters. The result of the combination of demand management policies was a nearly $20 \%$ drop in municipal water consumption between 2007 and 2009 (see Figure 2). Already by 2008, consumption of natural sources of freshwater had dropped to its lowest levels since 1967 [46].

\section{Tradeoffs between Supply and Demand Management Policies}

Seemingly, Israel had succeeded in both significantly reducing demand and increasing supplies. However, several events and issues have presented challenges to this mutual coexistence. As of 2011, Israel was no longer depleting its aquifers and the level of the Sea of Galilee had risen to well above the red-line (though still well below its full capacity). Government officials and water managers, proud of their achievements in rapidly increasing the amount of freshwater supplies, and also wanting to justify the cost increases to the population, came out with statements to the effect that Israel was no longer suffering from a water shortage. For instance, Uri Shani, the former head of the Water Authority, was quoted as saying in 2011 that Israel was already overcoming "the critical water shortages" it had been facing. Despite comments by other officials that "the hydrological crisis that the State of Israel has been in over the past years is far from over. The country's citizens must still continue to conserve", the headlines of the paper read "The Departing Director of the Water Authority: Israel's Water Crisis is Over" [47].

In the same vein, in 2013, Uzi Landau, then serving as Minister of National Infrastructures, which oversees the Water Authority, stated in an interview "Today, it can be claimed with confidence that the water crisis is behind us" [48]. He said that a combination of both additional supplies from desalination and reduced demand due to campaigns and pricing had achieved "stability" in the water sector. According to one observer, by 2013 the Israeli government had declared "water independence from weather" [49].

Statements such as these, together with a de-emphasis of demand management measures, caused many people to conclude that water in Israel was no longer scarce. Public protest at the rapid and dramatic increase in tariffs for water, led to pressure on policymakers to reduce prices. A conservation fee imposed on the highest tier of a three-tiered municipal water tariff (i.e., on the biggest water consumers) was ceased in 2009 only several months after it was initiated. Between 2013 and 2016, both average and marginal real prices for municipal water were reduced by nearly $20 \%$ (based on data 
from [43]); this, despite the fact that expenditures for water represent only $1 \%$ of household disposable income (based on [50]) and the fact that, as of 2013, average tariff rates for municipal water in Israel were lower than average for OECD countries [51].

In addition, the government, weary of "conservation fatigue" on the part of consumers, changed the nature of their campaigns. In 2010 and 2011, it asked consumers to "hold out" and keep conserving for another bit until further desalination came online. By 2012, it had stopped major conservation campaigns altogether.

While, in essence, the additional desalinated water had merely allowed Israel to cease withdrawing beyond natural recharge rates. The statements of policymakers confidently singing the praises of desalination and declaring an end to the water crisis, were seen by many as evidence that water was no longer scarce, and even that Israel now had water surpluses. For instance, a writer of a recently published book on Israeli water management stated that Israel was "not just water secure but even abundant" [52]. Similar views were shared by water officials and the media. For instance, in 2014, Avraham Tenne, head of the desalination division of Israel's Water Authority, stated "We have all the water we need, even in the year which was the worst year ever regarding precipitation" [53]. An article on "the end of Israel's water shortage" stated "Remember all the years of being told to conserve 'every drop'? Well, times have changed: Today, Israel has so much affordable water, it can offer to export it." [54].

A survey conducted for the purposes of this article in early 2016 asked a random sample of 70 Israeli adults a number of questions about their perception of water resources in Israel. When posed the question of whether or not Israel faced water scarcity, less than 38\% indicated that they believed Israel faced water scarcity (Table 1). Nearly half of respondents indicated that they believed that Israel had faced scarcity in the past, but no longer did, due to desalination, while almost $15 \%$ believed that Israel had never faced scarcity.

Table 1. Public perceptions of water scarcity $(n=70)$.

\begin{tabular}{cc}
\hline Attitude towards National Water Scarcity & Percent of Respondents \\
\hline Israel faces water scarcity & $37.5 \%$ \\
Israel did face water scarcity in the past, but no longer does & $47.8 \%$ \\
Israel has never faced water scarcity & $14.5 \%$ \\
\hline
\end{tabular}

As a result of the decline in the implementation of demand management measures, together with the decrease in public perception of scarcity due to desalination, both overall water consumption and consumption of freshwater have increased each year since 2011 (see Figure 2b). Municipal consumption also increased, both in aggregate and per capita terms, each year since 2011 (Figure 2c). Per capita municipal consumption in 2014 was more than 7\% higher than 2011 levels (based on data from [41]). Thus, much of the effect of the previous demand management measures was essentially eroded during this period.

The increased consumption would not be problematic if supplies were, in fact, greater than demand. However, that was not the case. Israel and its neighbors, which also suffer from chronic water scarcity, have growing populations. Jordan also has the additional burden of supplying water for hundreds of thousands of Syrian refugees, and Israel has obliged by increasing water transfers to Jordan. Furthermore, Israel and the region are still prone to drought conditions. As a result of a combination of scant rainfall in the north of the country in 2014 and 2015, and increased consumption, the level of Sea of Galilee was once again below the red-line as of late 2015 and early 2016 (Figure 1), this despite a significant reduction in withdrawals from the lake in recent years.

The impression that water is no longer scarce is in stark contrast to the fact, that, as mentioned earlier, even with the addition of desalination, according to the Falkenmark index, Israel is still solidly in the category of countries suffering from chronic water scarcity. The additional desalination capacity has brought annual freshwater supplies to only slightly higher than the original estimate of $1600 \mathrm{mcm}$ that had served water planning in Israel for decades. In addition, the country still has huge historical 
deficits of water, depleted aquifers, and a legacy of desiccated streams. According to the former Minister of National Infrastructures Uzi Landau, historical over-withdrawals meant that Israel faced a cumulative water debt of 1500-2000 mcm that needed to be restored to nature [55]. This is three to four times the total amount of annual desalination capacity, and is likely to take years to replenish. These facts seem clearly at odds with the public perception, often promoted by government officials, that Israel no longer faces water scarcity.

\section{Discussion}

From the data presented in the previous section, it seems that the supply-side policies served to diminish the once successful demand-side management measures that were in place. The dynamic at play appears to be more than simply a market reaction to increased supply. In theory, the increase in consumption could simply be due to the lowering of tariff rates over the past two years. Even if this were the case, it still could support the claim that expanded supplies undermined demand management, since much of the rationale for these price decreases was itself due to pressure from the public that was convinced that water was no longer scarce, and thus, high prices no longer justified. However, it does not appear that the increased consumption was primarily in response to price decreases. The increase in consumption has been continuous since 2011, while prices began to decline only in 2013 (see Figures 2c and 3). In addition, the price decline in the last few years did not get nearly the media attention that price increases did. Thus, most of the public is unaware of the price decrease, and so is unlikely to have changed behavior in response.

In the survey conducted for this study in 2016, when given ranges of prices for a cubic meter of water, only $17 \%$ of those surveyed correctly identified the range covering the actual price range over the last eight years, while an identical percentage chose price ranges higher than the prices at their peak level in 2013, and over 62\% answered that they had no idea. More importantly, when asked about the change in water prices over the last two and half years, only $13 \%$ correctly indicated that they had declined (all indicating a "slight decline"), while over $65 \%$ answered that they had increased, with over $26 \%$ replying that they had increased substantially (Table 2 ). This lack of public awareness of water prices confirms similar findings from earlier surveys (e.g., [56]).

Table 2. Public perception of price changes over the past two years $(n=70)$.

\begin{tabular}{cc}
\hline Perception of Price Change & Percent of Respondents \\
\hline Decreased substantially & $0.0 \%$ \\
Decreased slightly & $13.0 \%$ \\
Remained the same & $21.7 \%$ \\
Increased slightly & $39.1 \%$ \\
Increased substantially & $26.1 \%$ \\
\hline
\end{tabular}

A few conclusions can be inferred from such findings. One is that price decreases have not been widely felt by the public, and, thus, are unlikely to explain much of the increase in consumption over the last years. The increase in consumption began during a period following the cessation of public campaigns, during which prices were actually increasing. This seems to indicate both that prices have been, at best, a crude tool for regulating consumption over the past years, and that public campaigns and perceptions seem to play an important role in impacting consumption.

Following official government committee investigations into the causes of the water management crisis in 2010 [57], policymakers were eager both to demonstrate that they had taken significant steps to alleviate the situation, as well as to justify the costs of their primary solution, desalination. Their response was to tout the merits of desalination as a permanent solution to the nation's water shortages. While in the interim, desalination had merely obviated the need for further overdrafts, a common perception was that the country now had surpluses and had solved the issue of water scarcity completely. Given this perception, it will be difficult to once again convince the public to conserve. 
As such, an effective demand management tool is essentially no longer available, even at a time when reserves are at critically low levels, even below the so-called red-lines.

\section{Conclusions}

Water managers are always likely to seek a mix of supply and demand management strategies. Ideally, these tools would be complementary and their impact additive. This study aimed to show a potential trade-off between supply and demand-side policies, namely, the risk of moral hazard, by which consumers, knowing that additional supplies are available or are soon to be available, discount the need for conservation.

One should be careful not to infer from this case study that increased supplies will always detract from conservation efforts. In the case examined, policymakers, for various reasons, perhaps overstated the contribution of desalination to alleviating the country's water shortages. Arguably, the media also contributed by oversimplifying and misrepresenting the situation.

It is possible that better planned policy could have avoided much of the undesired impacts. For instance, the rapid increase in prices caused public outrage. In order to justify the costs of desalination, policymakers responded by emphasizing that desalination would solve the country's water shortages. A more gradual increase of costs may have reduced some of the need to tout desalination's benefits, and, as a result, also may have avoided some of the public backlash. This also may have avoided the need for an eventual decrease in tariffs that came as a response to the backlash.

Continuation of conservation campaigns, even as new supplies were coming online, could also have prevented the perception that water was no longer scarce. Finally, while policymakers are largely not responsible for media coverage of their actions, better care could have been taken to ensure more accurate and nuanced coverage that emphasized that water scarcity was still an ever-present issue. While there was responsible journalism, which attempted to remind the public that shortages were not a thing of the past and that conservation was still warranted (e.g., [58,59]), it was largely reacting to the already ingrained perception that water was now abundant.

Challenges in achieving coexistence in Israel seem also to apply to the field of water policy options. Expanding available supplies by means of desalination is seen as the bulwark of Israel's long-term water plan [20]. These supply augmentation efforts, however, have, intentionally or not, eroded the effectiveness of various demand management policies implemented over the course of the last several years. The lesson for water managers is that special care needs be taken to ensure that provision of increased supplies does not undermine conservation objectives. This is likely to entail coordinated pricing policies as well as specific strategies to communicate to the public the importance of continued conservation.

Conflicts of Interest: The author declares no conflict of interest.

\section{Abbreviations}

The following abbreviations are used in this manuscript:

IWRM Integrated Water Resource Management

IPCC International Panel on Climate Change

MCM Million cubic meters

NWC National Water Carrier

OECD Organization of Economic Cooperation and Development

\section{References}

1. Dziegielewski, B. Strategies for Managing Water Demand. Water Resour. Update 2003, 126, 29-39.

2. Dolatyar, M.; Gray, T. Water Politics in the Middle East: A Context for Conflict or Cooperation? Palgrave Macmillan: Basingstroke, Hampshire, UK; New York, NY, USA, 2000. 
3. Gleick, P.H. Global Freshwater Resources: Soft-Path Solutions for the 21st Century. Science 2003, 302, 1524-1528. [CrossRef] [PubMed]

4. Brandes, O.; Brooks, D. The Soft-Path for Water in a Nutshell. In Friends of the Earth Canada; POLIS Project on Ecological Governance; University of Victoria: Victoria, BC, Canada, 2007.

5. Butler, D.; Memon, F.A. (Eds.) Water Demand Management; IWA Press: London, UK; Seattle, WA, USA, 2006.

6. Shafik, N.; Bandyopadhyay, S. Economic Growth and Environmental Quality: Time Series and Cross-Country Evidence; World Bank: Washington, DC, USA, 1992.

7. Gleick, P. (Ed.) The World's Water Volume 8: The Biennial Report on Freshwater Resources; Island Press: Washington, DC, USA, 2014.

8. The United Nations Children's Emergency Fund (UNICEF); World Health Organization. Progress on Sanitation and Drinking Water-2015 Update and MDG Assessment; WHO Press: Geneva, Switzerland, 2015.

9. Mekonnen, M.M.; Hoekstra, A.Y. Four billion people facing severe water scarcity. Sci. Adv. 2016, 2. [CrossRef] [PubMed]

10. Alavian, V.; Qaddumi, H.M.; Dickson, E.; Diez, S.M.; Danilenko, A.V.; Hirji, R.F.; Puz, G.; Pizarro, C.; Jacobsen, M.; Blankespoor, B. Water and Climate Change: Understanding the Risks and Making Climate-Smart Investment Decisions; World Bank: Washington, DC, USA, 2009.

11. Cooley, H. Water Management in a Changing Climate. In The World's Water Volume 6: The Biennial Report on Freshwater Resources; Gleick, P., Ed.; Island Press: Washington, DC, USA, 2008.

12. Miller, K.A. Climate Change and Water Resources: The Challenges Ahead. J. Int. Aff. 2008, 61, 35-50.

13. Jønch-Clausen, T.; Fugl, J. Firming up the Conceptual Basis of Integrated Water Resources Management. Int. J. Water Res. Dev. 2001, 17, 501-510. [CrossRef]

14. Global Water Partnership. Sharing Knowledge for Equitable, Efficient and Sustainable Water Management; Global Water Partnership: Stockholm, Sweden, 2003.

15. Borchardt, D., Ibisch, R., Eds.; Integrated Water Resources Management in a Changing World: Lessons Learnt and Innovative Perspectives; IWA Publishing: London, UK, 2013.

16. Dixon, A.M.; McManus, M. An Introduction to Life-Cycle and Rebound Effects in Water Systems. In Water Demand Management; Butler, D., Memon, F.A., Eds.; IWA Press: London, UK; Seattle, WA, USA, 2006.

17. Berbel, J.; Gutiérrez-Martín, C.; Rodríguez-Díaz, J.A.; Camacho, E.; Montesinos, P. Literature Review on Rebound Effect of Water Saving Measures and Analysis of a Spanish Case Study. Water Resour. Manag. 2014, 29, 663-678. [CrossRef]

18. Central Bureau of Statistics (Israel). Population. Table B/1.-Population, By Population Group. Available online: http://www1.cbs.gov.il/webpub/pub/text_page_eng.html?publ=93\#2 (accessed on 8 February 2016).

19. Yakobovitz, M. Water in Israel; Shikmona Publishing Company: Haifa, Israel, 1971. (In Hebrew)

20. Israel Water Authority. Long-Term Master Plan for the National Water Sector Part A-Policy Document Version 4. Available online: http://www.water.gov.il/Hebrew/Planning-and-Development/Planning/ MasterPlan/DocLib4/MasterPlan-en-v.4.pdf (accessed on 30 December 2015).

21. Falkenmark, M.; Lindh, G. Water for a Starving World; Westview Press: Boulder, CO, USA, 1976.

22. Alpert, P.; Krichak, S.O.; Shafir, H.; Haim, D.; Osetinsky, I. Climatic trends to extremes employing regional modeling and statistical interpretation over the E. Mediterranean. Glob. Planet. Change 2008, 63, 163-170. [CrossRef]

23. Paz, S.; Kutiel, H. Rainfall Regime Uncertainty (RRU) in an Eastern Mediterranean region-A methodological approach. Israel J. Earth Sci. 2003, 52, 47-63. [CrossRef]

24. The World Bank. The Little Data Book on Climate Change 11; The World Bank: Washington, DC, USA, 2012.

25. Ziv, B.; Saaroni, H.; Baharad, A.; Yekutieli, D.; Alpert, P. Indications for aggravation in summer heat conditions over the Mediterranean basin. Geophys. Res. Lett. 2005, 32, L12706. [CrossRef]

26. Shilo, E.; Ziv, B.; Shamir, E.; Rimmer, A. Evaporation from Lake Kinneret, Israel, during Hot Summer Days. J. Hydrol. 2015, 528, 264-275. [CrossRef]

27. Golan-Engelko, I.; Bar-Or, Y. Israel's Preparation for Global Climatic Changes, Phase I-The Implications of Climate Change for Israel: Ministry of Environmental Protection. 2008. Available online: http://www.sviva.gov.il/Enviroment/Static/Binaries/ModulKvatzim/adaptation_report_to_yeshayahu _revised_2010-_remarks_2.pdf (accessed on 14 January 2015). 
28. Sowers, J.; Vengosh, A.; Weinthal, E. Climate change, water resources and the politics of adaptation in the Middle East and North Africa. Clim. Chang. 2011, 104, 599-627. [CrossRef]

29. Melloul, A.J.; Collins, M.L. Hydrological changes in coastal aquifers due to sea level rise. Ocean Coast. Manag. 2006, 49, 281-297. [CrossRef]

30. Feitelson, E. The Four Eras of Israeli Water Policies. In Water Policy in Israel; Becker, N., Ed.; Springer: Dordrecht, The Netherland, 2013.

31. Tal, A. Pollution in a Promised Land: An Environmental History of Israel; University of California Press: Berkeley, CA, USA, 2002.

32. Tal, A.; Katz, D. Rehabilitating Israel's Streams and Rivers. Int. J. River Basin Manag. 2012, 10, 317-330. [CrossRef]

33. Israel Water Commission. The Water in Israel-Consumption and Production 1962-1970; Ministry of Agriculture: Tel Aviv, Israel, 1972.

34. Gagin, A.; Neumann, J. The Second Israeli Randomized Cloud Seeding Experiment: Evaluation of the Results. J. Appl. Meteorol. 1981, 20, 1301-1311. [CrossRef]

35. Gvirtzman, H. Water Resources in Israel; Yad Ben-Zvi: Jerusalem, Israel, 2002. (In Hebrew)

36. Rangno, A.L.; Robbs, P.V. A New Look at the Israeli Cloud Seeding Experiments. J. Appl. Meteorol. 1995, 34, 1169-1193. [CrossRef]

37. Israel Water Authority. The Wastewater and Treated Effluents Infrastructure Development in Israel. Available online: http:/ / water.gov.il/Hebrew/ProfessionalInfoAndData/2012/03-The\%20Wastewater\%20 and \%20Treated\%20Effluents\%20Infrastructure\%20Development\%20in\%20Israel.pdf (accessed on 26 March 2015).

38. Kislev, Y. The Water Economy of Israel, Policy Paper No. 2011.15; The Taub Center for Social Policy Studies in Israel: Jerusalem, Israel, 2011.

39. Katz, D. Policies for Water Demand Management in Israel. In Water Policy in Israel: Context, Issues and Options; Becker, N., Ed.; Springer Press: Dordrecht, The Netherland, 2013.

40. Israel Water Authority. Kinneret Water Levels. Available online: http://water.gov.il/Hebrew/ WaterResources/Kinneret-Basin/Pages/default.aspx (accessed on 8 February 2016). (In Hebrew)

41. Israel Water Authority. Consumption Survey 2014. Available online: http://water.gov.il/Hebrew/ ProfessionalInfoAndData/Allocation-Consumption-and-production/Pages/Consumer-survey.aspx (accessed on 8 February 2016). (In Hebrew)

42. Kislev, Y. Water in Agriculture. In Water Policy in Israel: Context, Issues and Options; Becker, N., Ed.; Springer Press: Dordrecht, The Netherland, 2013.

43. Israel Water Authority. Water Tariffs. Available online: http://water.gov.il/Hebrew/Rates/Pages/Rates.aspx (accessed on 8 February 2016). (In Hebrew)

44. Lavee, D.; Danieli, Y.; Beniad, G.; Shvartzman, T.; Ash, T. Examining the Effectiveness of Residential Water Demand-side Management Policies in Israel. Water Policy 2013, 15, 585-597. [CrossRef]

45. Katz, D.; Grinstein, A.; Kronrod, A.; Nisan, U. Comparing marketing and price and mechanisms for water conservation. J. Environ. Manag. 2016, in press.

46. Rinat, T. Water Consumption from Natural Sources the Lowest Since '67. Haaretz, 6 April 2008. Available online: http:/ / www.haaretz.co.il/misc/1.1316400 (accessed on 6 April 2008). (In Hebrew)

47. Cohen, A. The Departing Director of the Water Authority: Israel's Water Crisis is Over. Available online: http:/ / www.themarker.com/news/1.643631 (accessed on 18 May 2011). (In Hebrew)

48. Landau, U. Today, it can be claimed with confidence that the water crisis is behind us. Mayim V'Hashkaya (Water and Irrigation) 2013, 8-12. (In Hebrew)

49. Siegel, S. Let There Be Water: Israel's Solution for a Water-Starved World; Thomas Dunne Books/St. Martin's Press: New York, NY, USA, 2015.

50. Central Bureau of Statistics (Israel). The 2013 Household Expenditure Survey. Table 1.1.-Monthly Income And Consumption Expenditure. Available online: http://cbs.gov.il/publications15/1613/pdf/t01_01.pdf (accessed on 2 April 2016).

51. OECD. Environment at a Glance 2015: OECD Indicators; OECD Publishing: Paris, France, 2015.

52. Siegel, S. Water Blog-A Cinderella Moment. Available online: http://www.sethmsiegel.com/ a-cinderella-moment/ (accessed on 8 February 2016). 
53. The Associated Press. Israel's Desalination Program Averts Future Water Crises. Haaretz, Available online: http://www.haaretz.com/israel-news/science/1.596270 (accessed on 31 May 2014). (In Hebrew)

54. Elizur, Y. Over and Drought: Why the End of Israel's Water Shortage Is a Secret. Haaretz, Available online: http:/ / www.haaretz.com/israel-news/1.570374 (accessed on 24 January 2014). (In Hebrew)

55. Trilnik. Uzi Landau: By the End of the Decade Israel's Water Problems Will be Solved. The Marker, Available online: http:/ / www.themarker.com/misc/article-print-page/1.1740828 (accessed on 26 May 2012). (In Hebrew)

56. National Investigative Committee. Report of the National Investigative Committee for the Management of the Water Sector in Israel; National Investigative Committee: Haifa, Israel, March, 2010. (In Hebrew)

57. Peled, M. Survey: 77\% of the Public do not Know How Much They Will Pay for Water. Calcalist, Available online: http:/ / www.calcalist.co.il/local/articles/0,7340,L-3380543,00.html. (accessed on 30 December 2009). (In Hebrew)

58. Porat, T. Waiting for the Desalination Tidings. Ynet, Available online: http://www.ynet.co.il/articles/0,7340, L-4137270,00.html (accessed on 22 October 2011). (In Hebrew)

59. Lavee, A. The Water Crisis, Remember? NRG. Available online: http://www.nrg.co.il/online/1/ART2/ 285/878.html (accessed on 15 September 2011). (In Hebrew)

(C) 2016 by the author; licensee MDPI, Basel, Switzerland. This article is an open access article distributed under the terms and conditions of the Creative Commons Attribution (CC-BY) license (http://creativecommons.org/licenses/by/4.0/). 